Article

\title{
Green Victimology View in Iranian Criminology System
}

\author{
Nima Norouzi $\left.{ }^{(}\right)$, Muhammad Sheikhi ${ }^{*}$, Heshmat-Ullah khanmohammadi ${ }^{\circledR}$, Mahmood Jafari ${ }^{(D)}$, Soheila \\ Kalantari ${ }^{\circledR}$, Soheila Vaziri Narani ${ }^{\circledR}$, Ali Shaebani ${ }^{\circledR}$
}

Law and criminology department, Islamic Azad University, Tehran, Iran

*Correspondence: sheikhim438@gmail.com

\begin{abstract}
Green or environmental victimology is one of the branches of green criminology that emerged in the 1990s with the criminal justice system's critical origins instead of conventional victimology. In contrast, green victimology believes that human beings can be green victims alongside nature. By following the rules of Iran's legislative penal policy, green victims can be divided into living and inanimate categories. Living green victims are people, animals, trees, plants, and inanimate green victims divided into air, water, soil, and earth. Although the Iranian legal system considers both groups as green victims and is therefore influenced by a nature-oriented approach, many challenges support them in these regulations, and portraying them can play a valuable role in identifying and protecting them. Green victims play. Therefore, in this study, the first goal is to identify green victims, and the second goal is to express the extent of the legislator's support for green victims and the challenges it faces.
\end{abstract}

Keywords: Water, Environment, Pollutants, Convention, Legislative Policy.

How to cite this paper : Norouzi, N., Sheikhi, M., khanmohammadi, H.U., Jafari, M., Kalantari, S., Vaziri Narani, S., \& Shaebani, A. (2021). Green Victimology View in Iranian Criminology System. Research Journal of Ecology and Environmental Sciences, 1(2), 82-95. Retrieved from https://www.scipublications.com/journal/index.php/rjees/article/view/101

Received: July 22, 2021 Accepted: August 24, 2021 Published: August 25, 2021

Copyright: (C) 2021 by the authors. Submitted for possible open access publication under the terms and conditions of the Creative Commons Attribution (CC BY) license (http://creativecommons.org/licenses /by/4.0/).

\section{Introduction}

Today, the right to a healthy environment has been considered an important issue in the third generation of human rights in the international system's right to solidarity. In the domestic system, too, most countries address environmental issues in their constitutions and prohibit harm. For this reason, this has led to the process of "fundamentalization of the right to the environment" [1]. However, there are damages such as the production of hazardous waste, global warming, ozone depletion, deforestation, smuggling of rare animal and plant species, severe environmental pollution, acid rain, and depletion of water resources, which in addition to the environment, Destroys and challenges human life [2].

The important question behind these injuries is who or what exactly is their victim. In other words, who is the victim of environmental crimes? In response, it should be noted that although environmental crimes are considered victimless crimes $[3,4]$, in terms of the green victimology approach first introduced in 1996 by Christopher Williams [5] This statement does not correspond to reality. The green victimology approach, which seeks to express the limited scope of criminal law in identifying green victims [6], seeks to look at victims of environmental crimes with a critical view and different from conventional victimology. Green victimology has a discourse beyond conventional victimology that has always had a humanistic approach and has introduced human beings as victims; What green victimology is talking about, in addition to humans, also about people other than humans who, until a few decades ago, criminology and victimology were unaware of them [7-9]. Although environmental damage has been neglected by criminology, in recent decades, the focus of criminology on environmental crimes has increased [10], one of the consequences of which has been the identification of non-humans as victims.

Thus, green victims can be identified in three categories: individuals, nature, and future generations. However, in this study, green victims will be examined in two categories 
of living victims (persons, animals, trees, and plants) and inanimate victims (air, water, soil, and earth); hence, although future generations in the category of potential victims. Environmental crimes are those whose process of victimization is due to negligence, carelessness, and actions of previous generations [11], but there will be no talk of victimization of future generations; Because they will be in one of these two groups, and their difference with the victimization of the current generation is only at the time of victimization.

But the point to be made in this regard is that the meaning of the green victim is everything that is but the essence of nature, not everything in nature. Therefore, the components of nature that are affected by green are air, water, soil, animals, trees, plants, and land; Thus, although environmental crimes may affect what exists in this material world (such as the impact of air pollution on historical and cultural artifacts), they will not be green victims; Because they are nothing but the essence of nature and are human artifacts[12].

The need to identify green victims can be seen in addition to the obligation of governments to apply Article 13 of the Declaration of the United Nations Conference on the Environment and Development, Rio 1992, which sets out "national legislation to identify victims of environmental pollution"; According to some criteria. A first measure is a large number of green victims, which means a large number of them. Unlike conventional crimes, which typically have a small number of victims, environmental crimes leave countless victims. The second measure is the diversity of green victims. Explain that humans are introduced as victims in normal crimes, while in environmental crimes, due to the ecosystem's continuity, if part of it is attacked, other parts are also victimized.

Finally, the third measure is the extent of green casualties. This measure means that green victims are not limited to the sovereign territories of countries and cross-border. In other words, crime sometimes has a transboundary aspect, such as the trade of rare animal and plant species or the illegal transfer of radioactive and hazardous substances (White, 2015: 13) and sometimes the effect of transboundary environmental crime, such as climate change caused by greenhouse gas emissions. Thus, in environmental crimes, what happens is that, firstly, the manifestations of nature do not belong to a particular country. Secondly, due to the effect of different environmental components on each other, other components become victims themselves if part of it is attacked. This is why transboundary environmental crimes significantly impact water, soil, air quality, endangered species, and climate change $[13,14]$.

This study aims to identify green victims, so Iranian criminal law in this area is explained to identify them. Then its shortcomings are criticized for taking a step to support these victims in Iranian criminal legislation. Therefore, this study's contents are divided into environmental living elements such as green victim (a) and inanimate environmental elements such as green victims (b).

\section{Living elements of the environment}

The living green victims are divided into four categories: individuals (1), animals (2), trees (3), and plants (4).

\subsection{Element of People}

Undoubtedly, humans have always suffered from environmental damage, so that different types of cancer and respiratory diseases can be caused by exposure to pollutants [15]. However, sometimes people are victims of environmental damage that they wear legally and are not criminal. In other words, there may be changes in the environment that are not environmental crimes [16]. For example, genetically modified (GMO) or transgenic crops such as oilseeds such as soybeans and corn have problems such as changes in food quality [17, 18], resistance to Antibiotics [19], Allergies [20, 21], Threats to plant genetic diversity [22], Toxins, Increased cancer, Food allergies, Genetic contamination, destruction of beneficial insects, soil fertility, weeds, and super insects are caused [23]. 
Although some countries have banned transgenic products due to the dangers, their use is prohibited in the Iranian legal system, but the Biosafety Law of the Islamic Republic of Iran adopted in 2009 emphasizes their existence. Article 2 of this law stipulates: "All matters related to the production, release, internal and transboundary transport, export, import, supply, purchase, sale, consumption, and use of genetically modified organisms are permitted following the provisions of this law and the government "It is obliged to make the necessary arrangements to do this through the non-governmental sector." However, according to paragraph c of Article 5 of the said law: Responsibility to protect human health and assess the potential hazards of deformed living organisms that consume human food, as well as the responsibility to identify and take the necessary measures for living organisms that directly "It is indirectly pathogenic to humans. It is the responsibility of the Ministry of Health, Treatment, and Medical Education."

But sometimes, humans are not as vulnerable to green, and some are more exposed to environmental damage than others. Two hypotheses can be made to explain this statement. The first is where a section of human beings are inadvertently harmed more than others, and the second is where environmental offenders select their victims and commit their environmental crimes against them. Regarding the first case, it should be noted that among certain human beings, two special groups, namely children and women (except for patients, of course), suffer more from environmental damage. According to World Health Organization researchers, children are the most vulnerable among environmental groups to environmental change; As in 2004, based on a study entitled "Earth Heirs" and "Study of the Atlas of Child Health and the Environment," children were introduced as the most vulnerable social strata [24].

Regarding the second case, it should be noted that empirical studies show that environmental hazards have many consequences for people of color, ethnic minorities, and Indigenous peoples in Australia, Canada, and the United States, and therefore, differential victimization patterns in the field of waste disposal. There is air pollution, chemical accidents, access to drinking water, etc[25].

Therefore, in the Iranian legal system, human victimization is explicitly recognized in environmental pollution. Note 2 of Article 688 of the Penal Code adopted in 1996 stipulates in this regard: "Environmental pollution means the diffusion or mixing of foreign substances into water or air or soil to the extent that its physical, chemical or biological quality be harmful to humans."

\subsection{Element of Animals}

In the traditional view of animals, they were considered a means to human wellbeing; Therefore, first, they were owned by human beings, and second, the owner had the right to deal with them. For this reason, in the classical Western tradition, animals are considered only as a machine in the service of man, and all the rulings concerning the relationship between man and animals were subject to a purely owner-object relationship; Therefore, hunters could easily take possession of them [26].

Hence, the chemist's view can be viewed from two perspectives. On the one hand, in the production of meat from animals, and on the other hand, the perpetration of behaviors such as the use of dogs for guarding or the finding of drugs by the police; Use of horses by police for patrols; Experiments on animals; Use in zoos and circuses; Harassment; Hunting, hunting, and trafficking in animals, but with the maturation of different ideas in dealing with animals, this view was pushed to the margins, and they gradually acquired rights that distanced themselves from being objects. Thus, in the theoretical dimension of protecting animals against human behavior with them, in addition to the field of applied ethics, a branch of which is called animal ethics/animal rights, researches on human behavior and interaction with animals [27]; Critical Criminology of Animal Species is a branch of critical criminology that emphasizes the identification and study of animals or non-human beings as victims of a wide range of acts, policies, and crimes committed by 
non-governmental and governmental institutions, humans and legal entities [28]. Therefore, this criminology calls for more study on animals and their protection areas [29]. Thus, both in international environmental law and in countries' domestic law, especially Iran, laws were adopted to protect animals, which is an important and valuable step in recognizing animals' rights.

In the Iranian legal system, at the beginning of the legislation, we see the existence of a traditional Western view of animals; On the one hand, according to Articles 17, 34, and 171 of the Civil Code, animals can be part of the property of individuals, and on the other hand, according to Articles 179 and 181 of this law, hunting will lead to the ownership of animals. Still, this view was moderated, and animal victimization was recognized. Examples include the Code of Criminal Procedure adopted in 1943, which states that "those who carry or keep birds or live animals hanging" (paragraph 12) and "those who harm live animals by whipping or something else in such a way as to cause injury" Or their bodily harm will be inflicted on them "(paragraph 17) The punishment was two to five days of imprisonment and ten to fifty rials in compensation. After that, laws related to hunting and animals' ownership-oriented view through hunting and fishing were rejected.

Animals in Iranian law can be victims of various crimes such as animal abuse, hunting, and trafficking; Therefore, there are three important laws in the Iranian legal system that criminalize each of these behaviors. First, the Hunting and Fishing Law approved in 1967 with subsequent amendments; The second is the Penal Code approved in 1996, and the third is the Law on Smuggling of Goods, and Foreign Exchange approved in 2013 (amended in 2015).

In the Iranian penal system, animals' victimization against hunting and physical injuries can be examined from their species' perspective. From this perspective, animals can be divided into two categories: terrestrial and aquatic. Terrestrial animals can be divided into wild and domestic groups. According to the Hunting and Trapping Act, there are three types of wildlife: normal wildlife, protected wildlife, and endangered wildlife.

Criminal protection of ordinary wild animals is provided in paragraph A of Article 10 of the Law on Hunting and Fishing, which carries a fine of one hundred thousand to one million rials or imprisonment of one to six months for the perpetrator. Therefore, in one of the judicial rulings, it is stated: "In the present case, Mr. ... is accused of hunting a fox ... he has been found guilty of a crime under Article 10 of the Law on Hunting and Trapping. He is sentenced to one day of imprisonment."

If the subject of the crime is a protected wild animal, according to Article 12, the amount of punishment will be from three months to three years or a fine from one million and five hundred thousand rials to eighteen million rials . Accordingly, one of the judicial rulings states: "Regarding the accusation of Mr. ... of illegal hunting of two boars, three tihu pieces and two ducks ... the defendant's delinquency was proven and documented in paragraph $b$ of Article 12 of the Law on Hunting and Fishing, a sentence will be issued for the convict mentioned above to pay a fine of eighteen million Rials"[11].

But if the subject is hunting rare wild animals such as Persian yellow deer, zebra, cheetah, and leopard, the amount of punishment according to Article 13 will be imprisonment from ninety-two days to three years, a fine from eighteen to twenty million rials . Thus, in one of the judicial verdicts, it is stated: "Regarding the accusation of Mr. ... that he hunted a leopard by committing a misdemeanor based on Article 680 of the Islamic Penal Code and paragraph A of Article 12 of the Hunting and Trapping Law, he is sentenced to two years in prison...". [12]

Articles 679 and 680 of the Penal Code are dedicated to hunting animals. The second part of Article 679 deals with the protection of animals whose hunting has been banned by the government and Article 680 with the protection of protected wild animals, considering that the law of hunting and fishing, in addition to species-specific criminality (nor- 
mal, protected, and rare animals), criminalizes Habitat-oriented (restricted, protected areas, wildlife sanctuary, national park); It was amended on December 15th, 1996, so the repeal of the mentioned articles is the law of punishments approved on May 22nd, 1996.

However, regarding the first part of Article 679, which provides criminal protection to law-abiding animals belonging to another, it should be stated that the protection of lawabiding animals is one of the objections of the legislator; Because how can one be guilty of killing another's chicken, but not one who destroys another's expensive guard dog? (Mir Mohammad Sadeghi, 2013: 221). In other words, the permissibility of meat of animals, the subject of the first part of this article, causes the exclusion of animals that are forbidden to eat and even those whose meat is disgusting. For example, we can refer to the wild "donkey," which in the current situation of the Iranian penal system remains without criminal protection; On the one hand, it has no owner, nor is he among the animals of lawful meat, and on the other hand, it is not one of the wild animals that the legislator has protected.

For this reason, sometimes the judicial procedure fills the mentioned legal gap by relying on other articles of the criminal law, which according to one of these opinions: "Regarding the accusation ... of committing a forbidden act by intentionally burning a live donkey's head and Injury to public opinion and chastity, considering that the accused tried to set fire to the donkey by pouring gasoline on it and that the donkey perished after several kilometers and 24 hours in an impressive condition ... Therefore ... his crime seems to be "It is clear that the court will sentence the accused to fifty lashes based on Article 638 of the Islamic Penal Code."

Regarding aquatic animals, it should be noted that the Law on Protection and Utilization of Aquatic Resources of the Islamic Republic of Iran, approved in 1995, is specifically dedicated to them; Therefore, their hunting is not subject to the law of hunting and fishing, but to the mentioned law.

Article 22 of this law, in order to provide criminal protection for water resources, criminalizes different behaviors, which include: carrying out fishing activities of foreign vessels in the waters under the rule of Iran (paragraph A); Fishing activities of Iranian people; Supply and transfer of aquatic animals for their reproduction and breeding; Redirection, creation of physical barriers and construction of any unauthorized installations in rivers designated as natural migration or reproduction routes, and creation of any pollution or spread of infectious diseases and discharge of industrial wastewater and any pollutants that cause damage to aquatic resources (paragraph b) And fishing in restricted areas; Fishing for species that are prohibited; Catching species for which permission has not been obtained; Fishing with illegal tools and equipment or keeping such tools and equipment on the vessel without obtaining a fishery license; Transportation and storage of illegally caught products on the vessel (paragraph c).

In addition to hunting, animals may also be victims of trafficking. Although the legislature had paid attention to animal trafficking in the laws on hunting and fishing and the law on protection and exploitation of water resources, once again in the new law on combating smuggling of goods and currency has standardized the protection of animals against smuggling, which has led to Past regulations on animal trafficking have been repealed. Article 25 of this law states in this regard: "Everyone shall live without legal permission from the Environmental Protection Agency and shall not comply with other provisions of the laws and regulations for the export of ordinary wild animals, endangered and rare, aquatic creatures, birds of prey and non-prey." "Whether it is a native or a wild migrant, whether alive or not, as well as the parts of these animals, or if accused is arrested during the export and deportation, even if his/her action does not lead to the departure of the mentioned cases, he/she will be sentenced to smuggling prohibited goods ...". Article 26, which explicitly causes Article 77 (d) of Article 22 of the Law on Protection and Exploitation of Aquatic Resources of the Islamic Republic of Iran, stipulates: "Catching, processing, preparation, supply, sale, transportation, storage and export of caviar and sturgeon "The amount and examples of which are determined by the Fisheries Organization, 
without the permission of this organization, is subject to the punishment of prohibited smuggling of goods."

\subsection{Element of Trees}

Due to the huge share of trees in the ecosystem and their relationship with the two phenomena of global warming and ozone depletion [28], Iranian criminal law has recognized the victimization of trees in two ways. First, the protection of trees that are part of an individual property; Such support is not to protect the environment and the intrinsic value of a tree but protect individuals' property. Second, trees protect trees because they are part of the national property and are considered public wealth. In the first case; In other words, criminal protection of trees belonging to individuals, the legislator has raised the flag of its criminal protection in two articles 675 and 684 of the Penal Code against harmful behaviors that somehow cause the death of trees. Article 675, which seeks to protect trees from "burning," provides: "Whoever intentionally burns ... a forest or ... trees or ... gardens belonging to another shall be sentenced to two to five years of imprisonment. "It is possible." Article 684, which is based on the criminal behavior of "destruction," stipulates: "Whoever ... destroys someone's orchard or grove or cuts and harvests another crop, or by stealing or cutting off the water that belongs to him." "It is either dried by other means or caused to be wasted ... He/she will be sentenced to six months to three years in prison and up to 74 lashes."

However, there are criticisms of the legislative criminal policy in the formulation of these two regulations. The first criticism can be made by asking a question about Article 675 , whether by using the plural in words forest, trees, and garden, all or at least most of them must be burned for Article 675 to be realized or by partial fire from a forest or a tree, the crime is committed. In response, two opinions can be raised.

First, Article 675 had a two-pronged view; On the one hand, a big look at the issue of crime, which is the forest, trees, and gardens, and on the other hand, a strict look at the criminal behavior, which is arson. Besides, the use of the plural nouns in the material implies a large behavior. Thus, the answer to this question should be considered negative, and it was believed that the mere burning of one tree, even if it belongs to another in the garden or forest, will not be covered by Article 675; It follows, therefore, that the burning of one or more trees belonging to another is not subject to criminal protection by the legislature because, on the one hand, the only article referring to the burning of trees is Article 675. Even Article 684 does not apply to it because of its criminal conduct. It is destruction, not arson, and on the other hand, citing Article 677 of the Penal Code, which stipulates: "Whoever intentionally destroys movable or immovable property belonging to another, or in any way, in whole or in part, or disables it." is a matter of discussion; Because both the material behavior of the crime in this article is not burning and destruction and the application of the object to the tree that is alive is not correct, but according to the second view, which is more defensible to protect the theoretical environment, the use of the plural in the phrase law does not prevent it from being applied to one of its instances. In other words, mere destruction of a part of property or damage to it is sufficient, and for the realization of a crime, the destruction of all property is not necessary [29]; Therefore, if someone burns a tree belonging to another, his behavior will be subject to Article 675 .

The second criticism is about the scope of Article 684 protection of all trees against destructive behavior. Explain that this article's criminal protection is protection based on the words "orchard, grove or other fields." Looking at the text of Articles 675 and 684, it is clear that in terms of criminal protection of trees, the scope of Article 684 is more limited than Article 675. Article 675 explicitly mentions forests, trees, and gardens belonging to another, while Article 684 does not explicitly mention this. Article 684 poses a challenge that raises whether this article, like Article 675, protects all trees, both fruitful and nonfruitful, or only for fruitful trees. 
On the one hand, looking at Article 684, it is clear that this article is based on protecting the fruit and the result. The use of terms such as "grazing another crop and destroying a vineyard, orchard or grove," and "cutting and reaping the crop" indicates that the legislator in this article is concerned with protecting the fruits and suffering of individuals and, therefore, the destruction of forests. Or trees belonging to another that does not bear fruit have not been considered by the legislator. Even concerning the protection of orchards, Article 675 has used it absolutely, while the criminal protection of Article 684 is limited to "orchards"; Therefore, it follows that the Iranian legislature did not criminalize the destruction of fruitless trees belonging to another and did not provide criminal protection for them[30].

But in the second case, where the legislature has raised criminal protections for national trees, unlike in the first case, there is no coherence, and this protection is exercised in scattered laws, which has created challenges to the validity of the laws protect them. Among the most important of these laws are the Law on Protection and Utilization of Forests and Rangelands approved in 1346; Law on Preservation and Protection of Natural Resources and Forest Reserves of the country approved in 1992; Law on Preservation and Expansion of Green Space in Cities approved in 1980 and amended in 2009 and the Law on Penalties[31]

By summing these rules together, we can identify two important harmful behaviors against trees, which are: burning and destroying. Fires are only explicitly mentioned in the law on the Protection and Utilization of Forests and Rangelands. In this law, in addition to burning each sapling and lighting a fire in the trunk of a forest tree, Articles 42 and 46, respectively, provide; The most important crime, namely causing forest fires, is defined in Articles 47 and 45 in both intentional and unintentional forms. Article 47 states: "Whoever intentionally starts a fire in the forest shall be sentenced to imprisonment ... from three to ten years ...". Article 45 states: "... if a fire breaks out in the forest as a result of negligence, the perpetrator shall be sentenced to imprisonment ... from two months to one year." The most important criticism of the legislator for the criminal protection of trees against fire behavior is that he bases his protection area only on forest trees. Thus if a nonforest tree is burned, the legislator's protection will be ended.

On the other hand, the destruction of trees can be examined in terms of their location. The first is that the trees are in a space other than the urban space, and the second is that they are located in such a space. In the first case, there is no objection to the discussion of fire; Because the law of protection and protection of natural resources and forest reserves of the country, approved in 1992, in Article 1, considers all tree species except the forest reserves of the country, and from this perspective, it does not matter whether these trees are in the forest environment or not; Because the supportive view of this article has been species-oriented, not location-oriented (forest)[33].

The most important regulation regarding trees in urban space is Article 4 of the law on amending the bill on preservation and expansion of green space in cities, approved in 2009, which has been repealed according to similar provisions to Article 686 of the Penal Code [32]. According to this article: "Whoever intentionally cuts or causes the destruction of the trees subject to Article (1) of the Green Space Development Law and in violation of the mentioned law, in addition to compensating the damage, as the case shall be fined or refind. "One million to ten million rials for each tree, and if more than thirty trees are cut down, he/she will be sentenced to six months to one year in prison."

However, there are three important points about this article that need to be mentioned. First, the legislator's performance in passing this article concerning Article 686 can be considered desirable on the one hand and undesirable on the other hand. The legislator's useful action in the new article can be considered as providing a fine for each tree separately, while Article 686 provided for a fine for the individual's behavior regardless of the number of trees cut down. Still, the unfavorable action of the legislator can be the 
decreasing the imprisonment period to six months. That means if the person was sentenced up to three years according to article 47 of the law on the Protection and Utilization of Forests and Rangelands, he/she can only be sentenced to up to one-year conditional imprisonment, as well as making the sentence conditional on cutting down more than thirty trees. Such a permit by the legislature allows individuals to cut down to thirty trees, and in return for such significant harmful behavior, which leaves many consequences, only a fine is imposed on the person until the offender violates more than thirty trees.

\subsection{Element of Plants}

A study of the Iranian penal system regarding plant mortality reveals a dual picture of it. On the one hand, the legislature believes in plants' intrinsic value, and on the other hand, it considers plants valuable when they are useful to other components of the environment. The most important manifestation of the first point of view of the legislator is shown in Note 2 of Article 688 of the Penal Code, according to which the distribution or mixing of foreign substances in water, air, soil, and land to the extent that changes its physical, chemical or biological quality to harmful plants has considered environmental pollution. Still, in the second view, the legislator has criminal protection of plants not for their intrinsic value, but in other ways. One of these aspects can be considered the role of plant habitat for animals. In addition to criminalizing animal protection, the law on hunting also provides criminal protection for their habitats[34].

This criminality can be divided into two categories based on the offender's physical behavior: destruction and arson. In the first behavior, depending on the plants' location, the punishment will be severe and weak. If the plants are in protected areas and wildlife sanctuaries, following paragraph " $\mathrm{d}$ " of Article 10, which stipulates: "for the destruction of plants, including pruning, planting, and illegal cutting, up to six months in prison is foreseen," but if these plants are in national parks and national natural monuments, the punishment for their destruction according to Article 12 will be three months to the year of imprisonment or from one million and five hundred thousand to eighteen million rials . Regarding the second behavior, namely arson, it should be stated that this behavior has been criminalized both intentionally and unintentionally. The unintentional case is provided in Article 13 (e), which makes no distinction between plants' presence in national parks, national natural monuments, protected areas, and wildlife sanctuaries. Still, in the case of deliberate arson, the plants must exist in national parks and national natural monuments to be covered by Note 1 of this article. Although these two behaviors are foreseen in one article, its unintentional case, according to the beginning of Article 13, will result in imprisonment from 91 days to three years or a fine from one million and eight hundred thousand Rials to twenty million Rials ; If its intentional case, according to the specification of Note 1, will lead to the realization of the punishment mentioned in Article 675 of the Penal Code, which is two to five years. In the Law on Protection and Utilization of Forests and Rangelands approved in 1967, the protection of plants is based on the prohibition on the one hand and crime on the other. Article 45 of this law prohibits plants' burning in farms and gardens in or near the forest to prevent forest fires. Therefore, since it has not declared a penalty for this prohibition, it does not fall within the scope of criminal protection, but Article 44 has provided criminal protection against the behavior of "grazing goats" in the forest and has imposed a fine for it[35].

\section{Inanimate elements of the environment}

Inanimate green victims are divided into four categories: air (1), water (2), soil (3), and land (4).

\subsection{Element of Air}

One of the most important effects of air pollution caused by greenhouse gas emissions is climate change. According to Article 1 of the Convention on Climate Change, this phenomenon means: "Climate change that is directly or indirectly due to human activities 
that change the world's atmosphere and is separate from the natural climate change that occurs in different periods.". This issue has become so important that international bodies such as the UN Human Rights Council have identified climate change as a threat to international peace and security, and two resolutions on "Human Rights and Climate Change" on March 28th, 2008 and March 25th, 2009 [15, 16].

In the Iranian legal system, the law on preventing air pollution, passed in 1995, is a special law that recognizes air pollution. Article 2 of this law stipulates: "Air pollution is the presence and spread of one or more pollutants, including solid, liquid, gas, radioactive and non-radioactive radiation in the open air in the amount and duration of its quality that is harmful to humans and other living things or plants or artifacts and buildings."

In this law, after stating the sources of air pollutants and their triple classification into motor vehicles; Factories, workshops, power plants, commercial and domestic resources, and miscellaneous resources for persons who cause air pollution, punishment is considered in Articles 28 to 32. The most important criminal behaviors in this law are traffic with polluting motor vehicles (Article 28); Violation of air pollution prohibitions (Article 28); Failure to comply with the rules, elimination of pollution, or cessation of activities causing air pollution by factories and workshops (Article 29) and pollution by commercial sources and public places (Article 31) and miscellaneous and domestic sources (Article 32).

Nevertheless, three points regarding air casualties in the Iranian legal system, especially the law, can be mentioned. First, the law does not provide adequate air protection against pollution. For example, crimes that can be committed by polluting motor sources with which only traffic has been criminalized; While it is obvious that traffic means passing through the passages, and if a motor vehicle turns on without traffic and produces pollution, the perpetrator can not be punished by relying on this substance. The second point can be asked in the form of a question, and that is whether air pollution is subject to Article 688 of the Penal Code regarding the threat to public health or not? In response, two opinions can be raised. First, air pollution can be punished through this substance; Because, in addition to Note 2 of the said Article, one of the aspects of environmental pollution is the diffusion or mixing of foreign substances into the air to the extent that it changes its physical, chemical or biological quality, the principle of the article is expressed in an allegorical way that can be generalized to air pollution. However, according to the second opinion, the answer to this question should be considered negative, and it is believed that air pollution is not covered by Article 688 and can be punished only according to the special law[36].

On the one hand, the law of legal penalties in general and the law on preventing air pollution is special, so according to the rules of principle, the general law does not abrogate the former. On the other hand, it does not seem logical that the legislator in Article 688 considers the same punishment for all the three categories of polluting sources. This punishment is considered imprisonment of up to one year, in which case the guarantee of execution of a person who drives a smoky vehicle is the same as that of a large factory owner who produces a large amount of pollution. Therefore, considering that the law on how to prevent air pollution for three categories of sources of contamination of motor vehicles and commercial, miscellaneous, and domestic sources provides for a fine and imposes imprisonment for only the owners of factories and workshops, these three categories can not be Punished according to Article 688 with a single execution guarantee and considered all three to be subject to this article. The third point is that what potentially diminishes the strength of air protection thinking is that the Iranian legal system recognizes air pollution if the resulting change is inevitable due to its harm to humans, other living organisms, plants, artifacts, and buildings. Air pollution is not recognized because of its intrinsic value but because it can be harmful to others.

\subsection{Element of Water}


In the Iranian legal system, although there is criminal protection for water dispersion and incoherence $[19,20]$, in some laws, water victimization against pollution is recognized. The most important laws that have been passed in this regard are Law on Hunting and Fishing, Law on water resources nationalization adopted in 1967, Law on Environmental Protection and development adopted in 1973, Law on Penalties and Law on the protection of seas and navigable rivers against petroleum pollution approved in 2010.

Article 1 of the Water Pollution Prevention Regulations stipulates: "Water pollution is the change of soluble or suspended matter or the change of temperature and other physical, chemical and biological properties of water to the extent that it is harmful to the consumption for which it is prescribed "To make it useless." Note 2: Article 688 of the Penal Code also considers the distribution or mixing of foreign substances in water as one of the aspects of environmental pollution to the extent that its physical, chemical or biological quality is changed in a way that is harmful to humans or other living organisms or plants or works or buildings[37].

Under different laws, the punishment for committing water pollution will vary depending on the type of water. According to Article 688 of the Penal Code, if the contaminated water is drinking water, it is one example of threats against public health for which the punishment of imprisonment is up to one year. If the water of rivers, lakes, protected wetlands, springs, and water sources are polluted, according to paragraph " $\mathrm{d}$ " of Article 12 of the Law on Hunting and Fishing, three months to three years imprisonment or a fine of one million and five hundred thousand to eighteen million rials will be taken. It is noteworthy that Article 688 of the Penal Code considers "dumping of poisonous substances in rivers" as an example of a threat to public health, which should be noted that in this case, paragraph " $\mathrm{d}$ " of Article 12 of the Law on Hunting and Fishing; Because according to the last part of Article 688, the punishment provided in the article will be applied when according to special laws, more severe punishment is not considered for the perpetrator. Finally, regarding the maritime regions of Iran, two cases must be distinguished. First, pollution of these waters with non-oil materials and second, pollution with petroleum materials. Regarding the first case, paragraph " $\mathrm{d}$ " of Article 13 of the Law on Hunting and Fishing will prevail, for polluting the water of the Caspian Sea and the Persian Gulf and the Sea of Oman, imprisonment from ninety-one days to three years or a fine of one million and eight hundred thousand Rials up to twenty million Rials. In the second case, the Law on the Protection of Navigable Seas and Rivers against Contamination with Petroleum Products for the Intentional Contamination of Marine Water is the subject of the Maritime Law of the Islamic Republic of Iran in the Persian Gulf and Oman Sea and waters under the rule of the Government of the Islamic Republic of Iran in the Caspian Sea and navigable rivers adopted in 2003 an Imprisonment from six months to two years or a fine of twenty million to five billion rials or both and for unintentional contamination of these waters fine of ten million rials to one billion rials has been considered[38].

However, although water damage is recognized in the Iranian legal system, this recognition is not due to water's intrinsic value. According to the law, water protection will be provided against pollution when it is detrimental to others. Explain that water damage is subject to its contamination in the mentioned laws to the detriment of humans or other organisms. For example, in Note 2 of Article 688, its negative change to the detriment of humans, animals, plants, monuments, and buildings is mentioned. The same position is taken in paragraph " $\mathrm{d}$ " of Articles 12 and 13 of the Law on Hunting and Fishing, in which criminal protection is subject to the fact that water pollution causes the loss of aquatic animals or endangers their environment. Such practices are still not seen in the law on the Protection of Navigable Seas, and Rivers against Contamination with Petroleum Products, and water pollution has been criminalized.

\subsection{Element of Soil}


In the Iranian penal system, soil can be the victim of two crimes of pollution and destruction. Soil contamination is criminalized as a threat to public health under Article 688 of the Penal Code. Although Article 688 does not mention soil contamination, it is allegorically stated that it constitutes the legal element of soil damage. According to this article: "Any action that is considered a threat to public health, such as contaminating drinking water or distributing contaminated drinking water, unsanitary disposal of human and animal wastes, dumping poisonous substances in rivers, garbage in the streets and unauthorized slaughter of livestock, the unauthorized use of raw sewage or wastewater from sewage treatment plants for agricultural purposes are prohibited," and perpetrators will be sentenced to up to one year in prison if they are not subject to more severe penalties under special laws." The important point here is that soil damage to pollution is not because of the soil's intrinsic value but because it may be detrimental to others. This is why Note 2 to Article 688 states: "Environmental pollution means the diffusion or mixing of foreign substances into ... soil ... to the extent that its physical, chemical or biological quality is such that human beings or other living organisms or plants or artifacts or buildings are harmed." Thus, if contaminants attack the soil, but this contamination is not to others' detriment, the victim will not be committing a criminal act. Also, if pollution enters other parts of the environment, the soil is not considered as a value that can be traced through; Therefore, if, for example, air pollution occurs, even if it is to the detriment of the soil, this environmental element will not be identified as damaged. Mentioning an example of judicial rulings in this regard can help clarify the extent of soil damage. Therefore, one of the judicial rulings states[39]:

"Regarding the accusation of Mr... that he polluted the environment by using fossil fuels instead of clean energy, which led to a threat to public health ... concerning the complaint that the plant ... uses diesel fuel in different seasons of the year, and with this action, more than 350 tons of sulfur dioxide enters the air of the surrounding areas daily ... and the high use of fuel oil and even the waste of Isfahan power plant has caused severe pollution in the region. continuation of pollution flow and effluent causes soil pollution, and in case of soil saturation and infiltration of groundwater, these waters will also be polluted ... These accusations are according to the Penal Code and Article 16 of the Law on How to Prevent Air Pollution, which sentences him to one year in prison." Therefore, in this verdict, soil damage due to effluent entry containing cyanide in the power plant has been recognized; No soil damage due to air pollution. In fact, in the current state of the Iranian legal system, soil can only be the victim of pollution and not the indirect victim of air pollution[40].

The second crime against soil is its destruction. In this regard, two legal provisions have provided criminal protection against destructive behavior in general and in particular. First, Article 690 of the Penal Code, which stipulates: "Whoever ... undertakes an operation that destroys the environment and natural resources ... shall be sentenced to one month to one year in prison." Second, Article 11 of the Law on Developed and Coastal Lands, approved in 1975, considers the destruction of lands through soil harvesting to be subject to imprisonment for up to three years; But two points about the crime of soil destruction can be mentioned in these two laws. First, Article 690 covers Iran's entire territory, while Article 11 covers emerging and coastal lands. Second, in Article 690, the soil is considered damaged, while in Article 11, soil harvesting is a means by which coastal lands are destroyed, and it doesn't mean the soil is damaged as an act of crime.

\subsection{Element of the land}

The meaning of land in this research is what is other than the main parts of the environment and belongs to the lithosphere and hydrosphere; Therefore, the land area is very wide and includes, for example, waterfalls, mountains, deserts, plains, springs, barren and desolate lands, pastures, shrubs, thorns, and shrubs. The most important crime against land in Iranian criminal law is its destruction. Article 690 of the Penal Code stipulates: "To 
somebody occupy or introduce themselves or others as the owner, or to carry out operations without the permission of the Environmental Protection Organization or other competent authorities that cause the destruction of the environment and natural resources in national parks, etc., ... to be punished from one month to one year of imprisonment". Special laws also recognize land damage, including the destruction of plants in protected areas and wildlife sanctuaries, national parks and natural monuments, the destruction of fountains and drinking water in protected areas and wildlife sanctuaries (Articles 10, 11 and 12 The Law on Hunting and Cutting and Eradication of Shrubs, Thorns, and Desert and Mountain Shrubs in Desert Areas (Article 43 of the Law on the Protection and Utilization of Forests and Rangelands)[41-44].

\section{Conclusion}

In the 1990s, green victimology emerged in the light of green criminology, which is itself a critical approach to the criminal justice system, to take a critical step in identifying victims of environmental crimes with a different perspective. Green Victimology seeks to prove that in addition to human victims, which is the nature of conventional victimology, it is possible to harm others other than humans who can be sacrificed; Therefore, we must change our view and consider nature as a victim along with human beings. Therefore, green victims can be identified from the perspective of green victimology in two categories of living things (persons, animals, trees, and plants) and inanimate objects (air, water, soil, and earth). Besides, future generations will be green victims and fall into the two categories mentioned. In Iranian criminal law, although there is no integrated and measured protection of the environment and its components, the prevailing approach is the nature-based view, according to which the victimization of the previous two categories is recognized. Iranian criminal law has introduced both individuals and nature as green victims. However, the challenges in this legal system should not be ignored. The lack of such coherence poses many challenges to implementing a desirable and prudent protectionist criminal policy, so the Iranian legislature must reform its environmental penal code. The Iranian legal system regarding environmental pollution lacks attention to life resources' intrinsic value, namely water, soil, and air. Therefore, the legislator must clarify the scope of his protection of green victims, especially the sources mentioned earlier against pollution, and pay attention to their intrinsic value by amending the laws. What is meant, then, is that although environmental components are interrelated, this relationship should not marginalize their intrinsic value, which requires the legislature to base its criminal protection on the intrinsic value of the environment, rather than raising its banner of protection when other components of the environment are damaged due to the violation of part of it.

\section{Supplementary Materials: "Not Applicable."}

Author Contributions: “Conceptualization, S.K. and M.S.; methodology, N.N.; software, M.J;; validation, H.K., S.V. and A.S.; formal analysis, N.N.; investigation, H.K.; resources, N.N.; writingoriginal draft preparation, H.K.; writing-review and editing, M.J.; supervision, N.N.; project administration, M.S. All authors have read and agreed to the published version of the manuscript."

Funding:: "This research received no external funding."

Data Availability Statement: "Not Applicable."

Acknowledgments: “Not Applicable."

Conflicts of Interest: "The authors declare no conflict of interest." 


\section{References}

[1] Smith, A. An Inquiry into the Nature and Causes of the Wealth of Nations; W. Strahan and T. Cadell: London, UK, 1776.

[2] Kasser, T. Materialistic Values and goals. Annu. Rev. Psychol. 2016, 67, 489-514. [PubMed]

[3] Shrum, L.J.; Lowrey, T.M.; Pandelaere, M.; Ruvio, A.; Gentina, E.; Furchheim, P.; Herbert, M.; Hudders, L.; Lens, I.; Mandel, N.; et al. Materialism: The good, the bad, and the ugly. J. Mark. Manag. 2014, 30, 1858-1881.

[4] Richins, M.L.; Dawson, S. A consumer values orientation for materialism and its measurement: Scale development and validation. J. Consum. Res. 1992, 19, 303-316.

[5] Dittmar, H.; Bond, R.; Hurst, M.; Kasser, T. The relationship between materialism and personal well-being: A meta-analysis. J. Pers. Soc. Psychol. 2014, 107, 879-924. [PubMed]

[6] Donnelly, G.E.; Ksendzova, M.; Howell, R.T.; Vohs, K.; Baumeister, R. Buying to blunt negative feelings: Materialistic escape from the self. Rev. Gen. Psychol. 2016, 20, 272-316.

[7] United Nations. World Population Prospects. 2019. Available online: https://population.un.org/wpp/Download/Standard/Population/ (accessed on 20 October 2020).

[8] Kwak, H.; Zinkhan, G.M.; French, W.A. Moral orientation: Its relation to product involvement and consumption. Adv. Consum. Res. 2001, 28, 431-436.

[9] Norris, J.I.; Lambert, N.M.; DeWall, C.N.; Fincham, F.D. Can't buy me love? Anxious attachment and materialistic values. Personal. Individ. Differ. 2012, 53, 666-669.

[10] Liu, J. Childhood externalizing behavior: Theory and implications. J. Child Adolesc. Psychiatr. Nurs. 2004, 17, 93-103.

[11] Okano, L.; Jeon, L.; Crandall, A.; Powell, T.; Riley, A. The cascading effects of externalizing behaviors and academic achievement across developmental transitions: Implications for prevention and intervention. Prev. Sci. 2020, 21, $211-221$.

[12] Bilsky, W.; Hermann, D. Individual values and delinquency: On considering universals in the content and structure of values. Psychol. Crime Law 2016, 22, 921-944.

[13] Froggio, G.; Lori, M. Deviance among young italians: Investigating the predictive strength of value systems. Int. J. Offender Ther. Comp. Criminol. 2010, 54, 581-596. [PubMed]

[14] Auerbach, R.P.; McWhinnie, C.M.; Goldfinger, M.; Abela, J.R.; Zhu, X.; Yao, S. The cost of materialism in a collectivistic culture: Predicting risky behavior engagement in Chinese adolescents. J. Clin. Child Adolesc. Psychol. 2009, 39, 117-127. [PubMed]

[15] Yang, Z.; Fu, X.; Yu, X.; Lv, Y. Longitudinal relations between adolescents' materialism and prosocial behavior toward family, friends, and strangers. J. Adolesc. 2018, 62, 162-170. [PubMed]

[16] Briggs, E.; Landry, T.; Wood, C. Beyond just being there: An examination of the impact of attitudes, materialism, and selfEsteem on the quality of helping behavior in youth volunteers. J. Nonprofit Public Sect. Mark. 2007, 18, 27-45.

[17] Reeves, R.A.; Baker, G.A.; Truluck, C.S. Celebrity worship, materialism, compulsive buying, and the empty self. Psychol. Mark. 2012, 29, 674-679.

[18] Noguti, V.; Bokeyar, A.L. Who am I? The relationship between self-concept uncertainty and materialism. Int. J. Psychol. 2014, 49, 323-333.

[19] Jiang, J.; Zhang, Y.; Ke, Y.; Hawk, S.T.; Qiu, H. Can't buy me friendship? Peer rejection and adolescent materialism: Implicit self-esteem as a mediator. J. Exp. Soc. Psychol. 2015, 58, 48-55.

[20] Awanis, S.; Schlegelmilch, B.B.; Cui, C.C. The myth of self-centeredness in materialism: Reconciling collectivism and materialism in Asia. In Rediscovering the Essentiality of Marketing. Developments in Marketing Science: Proceedings of the Academy of Marketing Science; Petruzzellis, L., Winer, R., Eds.; Springer: Cham, Switzerland, 2016.

[21] Górnik-Durose, M.E. Materialism and Well-Being Revisited: The Impact of Personality. J. Happiness Stud. 2020, 21, 305326.

[22] Hebben-Wadey, A. Materialism and Well-Being in Children. Ph.D. Dissertation, University College London, London, UK, 2011.

[23] Can, C. The relationship between materialism and self-transcendence in university students sample. Yeni Symp. 2013, 51, $13-22$.

[24] Chandler, M.J. Egocentrism and antisocial behavior: The assessment and training of social perspective-taking skills. Dev. Psychol. 1973, 9, 326-332.

[25] Greene, K.; Krcmar, M.; Walters, L.H.; Rubin, D.L.; Jerold; Hale, L. Targeting adolescent risk-taking behaviors: The contributions of egocentrism and sensation-seeking. J. Adolesc. 2000, 23, 439-461. [PubMed]

[26] Zhou, Z.; Shek, D.T.L.; Zhu, X.; Dou, D. Positive youth development and adolescent depression: A longitudinal study based on mainland Chinese high school students. Int. J. Environ. Res. Public Health 2020, 17, 4457. [PubMed]

[27] Zhou, Z.; Shek, D.T.L.; Zhu, X. The importance of positive youth development attributes to life satisfaction and hopelessness in mainland Chinese adolescents. Front. Psychol. 2020, 11, 2599.

[28] Zhu, X.; Shek, D.T.L. Impact of a positive youth development program on junior high school students in mainland China: A pioneer study. Child. Youth Serv. Rev. 2020, 114, 105022. 
[29] Shek, D.T.L.; Ma, C.; Lin, L. The Chinese adolescent materialism scale: Psychometric properties and normative profiles. Int. J. Disabil. Hum. Dev. 2014, 13, 285-295.

[30] Shek, D.T.L.; Yu, L.; Siu, A.M. The Chinese adolescent egocentrism scale: Psychometric properties and normative profiles. Int. J. Disabil. Hum. Dev. 2014, 13, 297-307.

[31] Shek, D.T.L.; Lin, L. Delinquent behavior in high school students in Hong Kong: Sociodemographic, personal, and family determinants. J. Pediatr. Adolesc. Gynecol. 2016, 29, S61-S71.

[32] Shek, D.T.L.; Zhu, X. Paternal and maternal influence on delinquency among early adolescents in Hong Kong. Int. J. Environ. Res. Public Health 2019, 16, 1338.

[33] Karabati, S.; Cemalcilar, Z. Values, materialism, and well-being: A study with Turkish university students. J. Econ. Psychol. 2010, 31, 624-633.

[34] Lipovčan, L.K.; Prizmić-Larsen, Z.; Brkljacic, T. Materialism, affective states, and life satisfaction: Case of Croatia. Springerplus 2015, 4, 699.

[35] Steinberg, L.; Elmen, J.D.; Mounts, N.S. Authoritative parenting, psychosocial maturity, and academic success among adolescents. Child Dev. 1989, 60, 1424-1436. [PubMed]

[36] Preacher, K.J.; Hayes, A.F. Asymptotic and resampling strategies for assessing and comparing indirect effects in multiple mediator models. Behav. Res. Methods 2008, 40, 879-891. [PubMed]

[37] Benson, P.L.; Scales, P.C.; Syvertsen, A.K. The contribution of the developmental assets framework to positive youth development theory and practice. In Advances in Child Development and Behavior; Lerner, R.M., Lerner, J.V., Benson, J.B., Eds.; Elsevier: New York, NY, USA, 2011; Volume 41, pp. 197-230.

[38] Lerner, R.M.; Lerner, J.V.; Lewin-Bizan, S.; Bowers, E.P.; Boyd, M.J.; Mueller, M.K.; Schmid, K.L.; Napolitano, C.M. Positive youth development: Processes, programs, and problematics. J. Youth Dev. 2011, 6, 38-62.

[39] Peterson, C.; Seligman, M.E. Character Strengths and Virtues: A Handbook and Classification; Oxford University Press: Oxford, UK, 2004; Volume 1.

[40] Shek, D.T.L.; Dou, D.; Zhu, X.; Chai, W. Positive youth development: Current perspectives. Adolesc. Health Med. Ther. 2019, 10, 131-141. [PubMed]

[41] Domitrovich, C.E.; Durlak, J.A.; Staley, K.C.; Weissberg, R.P. Social-emotional competence: An essential factor for promoting positive adjustment and reducing risk in school children. Child Dev. 2017, 88, 408-416.

[42] Ma, C.M.S.; Shek, D.T.L. Objective outcome evaluation of a positive youth development program: The Project P.A.T.H.S. in Hong Kong. Res. Soc. Work Pract. 2019, 29, 49-60.

[43] Ma, C.M.S.; Shek, D.T.L.; Chen, J.M.T. Changes in the participants in a community-based positive youth development program in Hong Kong: Objective outcome evaluation using a one-group pretest-posttest design. Appl. Res. Qual. Life 2019, 14, 961-979.

[44] Shek, D.T.L.; Lin, L.; Ma, C.M.; Yu, L.; Leung, J.T.Y.; Wu, F.K.Y.; Leung, H.; Dou, D. Perceptions of adolescents, teachers and parents of life skills education and life skills in high school students in Hong Kong. Appl. Res. Qual. Life 2020. Author 1, A.; Author 2, B. Title of the chapter. In Book Title, 2nd ed.; Editor 1, A., Editor 2, B., Eds.; Publisher: Publisher Location, Country, 2020; Volume 5, pp. 154-196. 